Review

https://doi.org/10.1631/jzus.B2100443
Check for updates

\title{
Electromagnetic field exposure as a plausible approach to enhance the proliferation and differentiation of mesenchymal stem cells in clinically relevant scenarios
}

\author{
Haslinda Abdul HAMID ${ }^{1}$, Vahid Hosseinpour SARMADI ${ }^{2,3}$, Vivek PRASAD ${ }^{4}$, Rajesh RAMASAMY $^{4}$, \\ Azizi MISKON ${ }^{1 凶}$ \\ ${ }^{1}$ Bio-artificial Organ and Regenerative Medicine Unit, National Defense University of Malaysia, Kuala Lumpur 57000, Malaysia \\ ${ }^{2}$ Cellular and Molecular Research Centre, Iran University of Medical Sciences, Tehran 1449614535, Iran \\ ${ }^{3}$ Institutes of Regenerative Medicine, Iran University of Medical Sciences, Tehran 1996714353, Iran \\ ${ }^{4}$ Stem Cell and Immunity Research Group, Immunology Laboratory, Department of Pathology, Faculty of Medicine and Health Sciences, \\ Universiti Putra Malaysia (UPM), Selangor 43400, Malaysia
}

\begin{abstract}
Mesenchymal stem/stromal cell (MSC)-based therapy has been regarded as one of the most revolutionary breakthroughs in the history of modern medicine owing to its myriad of immunoregulatory and regenerative properties. With the rapid progress in the fields of osteo- and musculoskeletal therapies, the demand for MSC-based treatment modalities is becoming increasingly prominent. In this endeavor, researchers around the world have devised new and innovative techniques to support the proliferation of MSCs while minimizing the loss of hallmark features of stem cells. One such example is electromagnetic field (EMF) exposure, which is an alternative approach with promising potential. In this review, we present a critical discourse on the efficiency, practicability, and limitations of some of the relevant methods, with insurmountable evidence backing the implementation of EMF as a feasible strategy for the clinically relevant expansion of MSCs.
\end{abstract}

Key words: Electromagnetic field; Proliferation; Mesenchymal stem cell; Therapy

\section{Introduction}

Discovered around 50 years ago in the bone marrow (BM), mesenchymal stem cells (MSCs) are a heterogeneous group of spindle-shaped cells with unique self-renewing and differentiation properties (Friedenstein et al., 1966). In many studies, MSCs have been observed to differentiate into distinct cells of the mesodermal lineage, including osteocytes, chondrocytes, and adipocytes (Pittenger et al., 1999; Kolf et al., 2007; Thibault et al., 2010; Ang et al., 2014; Somoza et al., 2014). Such propensity allows MSCs to be present almost ubiquitously at different sites within the human body, including but not limited to, adipose, umbilical cord, and amniotic fluid tissues (el Omar et al., 2014;

$\triangle$ Azizi MISKON, azizimiskon@upnm.edu.my

(D) Azizi MISKON, https://orcid.org/0000-0002-4267-4180

Received May 21, 2021; Revision accepted Aug. 22, 2021; Crosschecked Dec. 17, 2021

(C) Zhejiang University Press 2022 de Francesco et al., 2015; Mushahary et al., 2018). In addition, MSCs have been associated with various other biologically significant qualities, such as exerting antitumorigenic effects ( $\mathrm{Lu}$ et al., 2008; Sarmadi et al., 2008, 2020; Bruno et al., 2013), potent immunomodulatory activity (Ramasamy et al., 2010; Volarevic et al., 2017; Maqbool et al., 2020; Zhang et al., 2021), and lower rates of immunogenicity (Aggarwal and Pittenger, 2005; Barry et al., 2005; Klyushnenkova et al., 2005). These characteristics, coupled with fewer ethical cues (Fung et al., 2017; Volarevic et al., 2018), have generated a widespread interest among scientists and researchers alike, thereby making MSCs one of the most clinically studied cells in the platform of experimental cell therapy. For instance, in musculoskeletal clinical trials, autologous and allogeneic transplantations of MSCs were found to yield better performance in terms of post-operative healing and functional outcomes (Hashimoto et al., 2019; Song et al., 2020; Chung et al., 2021). Similar observations have been reported in 
several cases of psoriasis (Lee et al., 2017; Chen MS et al., 2019; Wang et al., 2020), ischaemic and nonischaemic cardiomyopathy (Butler et al., 2017; Florea et al., 2017; Hare et al., 2017), and even in corona virus disease 2019 (COVID-19)-related pneumonia (Leng et al., 2020; Liang et al., 2020; Shu et al., 2020; Tang et al., 2020). Further examples involve direct application of MSCs in the treatment and management of skin and sensory organ-related injuries (Ude et al., 2018), post-kidney transplantation (Erpicum et al., 2019), diabetes (types 1 and 2) (Jiang et al., 2011; Carlsson and Svahn, 2018), graft-versus-host disease (GvHD) (Kurtzberg et al., 2020), and multiple sclerosis (Connick et al., 2012; Iacobaeus et al., 2019).

Despite their numerous positive attributes, freshly isolated MSCs are rare and have high heterogeneity, and are in limited quantities because of factors such as age and gender (Alt et al., 2012; Fossett and Khan, 2012; Yang et al., 2018); therefore, an extensive expansion of the isolated cells is necessary to meet the growing demands of clinical experimental trials. However, extensive in vitro passages may undergo morphological, phenotypic, and genetic changes (Yang et al., 2018). Considerable efforts have been made to enhance the proliferation of MSCs in vitro without modifying their capabilities of stemness and differentiation. These include providing additional supplements, mainly growth factors (ascorbic acid, fibroblast growth factor-2 (FGF-2), platelet-derived growth factor with two subunits BB (PDGF-BB), and epidermal growth factor (EGF)) into their cultures (Solchaga et al., 2005; Choi et al., 2008; Tamama et al., 2010; Sun et al., 2013). Nevertheless, Gharibi and Hughes (2012) demonstrated that, even if given all of the supplementations, MSCs showed a marked decline in their differentiation ability and expression of stem cell genes after as few as $100 \mathrm{~d}$ of culture (Gharibi and Hughes, 2012). In this context, MSCs reaching senescence early would no longer be able to accommodate the need for translational medical therapies. This is because senescent cells, albeit in small numbers, could affect the functionalities of other organs and tissues through the release of secretomes containing proinflammatory molecules (Childs et al., 2015). Thus, clinically practical and cost-effective protocols are imperative for the proper generation and maintenance of MSCs.

\section{Potential of electromagnetic fields (EMFs) for MSC therapy}

Over the last few years, EMF has garnered attention as one of the most promising tools in stem cell therapy (Esposito et al., 2013; Ongaro et al., 2014; Miskon et al., 2018). EMF is a combination of electrical and magnetic fields, which can create non-ionized waves and non-thermal fields. Magnetic therapy encompasses a variety of approaches, which include EMF or pulsed EMF (PEMF). The latter is a type of electromagnetic therapy in which a small electrical current and low-frequency EMFs with specific waveforms and amplitudes, ranging between 6 and $500 \mathrm{~Hz}$, are intermittently applied to the body (Hu et al., 2020; Qiu et al., 2020). The application of EMF on living cells was found to induce a variety of effects not only at the cellular level, but also at the genomic level. In one study, the overexpression of p27 (cyclin-dependent kinase inhibitor), due to extremely low-frequency (ELF)EMF exposure, was found to lead to cell cycle arrest (Geng et al., 2014), while in another study, PEMF caused significant changes in the expression of programmed cell-death-related genes during different stages of apoptosis and necrosis (Kaszuba-Zwoinska et al., 2012). EMF exposure has also been linked to changes in DNA replication (Cheng and Zou, 2006) and cytokine expression (Jasti et al., 2001). As a form of therapy, EMF has been widely utilized in the treatment of bone fractures, as well as musculoskeletal and neuronal disorders, with high rates of success (Shupak et al., 2003). Interestingly, some findings suggested that, at predetermined time intervals and frequencies, EMF may also promote the proliferation of MSCs (Sun et al., 2009; Fan et al., 2015; Miskon et al., 2018) and could drive their cellular state of differentiation into chondrogenesis (Parate et al., 2017), osteogenesis (Kim et al., 2015), and even neurogenesis (Seong et al., 2014).

In light of these data, this paper aims to provide a concise review of current strategies employed for the culture and maintenance of MSCs in experimental laboratories. This includes a comprehensive analysis of factors and culture conditions related to long-term in vitro expansion of MSCs without compromising their "stemness." In addition, the underlying effects of EMF exposure on the proliferative, regenerative, and differentiation capacities of MSCs will be thoroughly discussed. Finally, we make brief evaluation of the 
deleterious impacts of EMF, if any, on cultures of MSCs.

\subsection{Effects of EMFs on the proliferation of MSCs}

In recent years, the effects of EMF exposure on the viability and proliferation of MSCs have been the topic of active research (Zhang et al., 2007, 2018; Sun et al., 2009; Song et al., 2014a; Fan et al., 2015; Marędziak et al., 2017; Ehnert et al., 2018; Ferroni et al., 2018; Miskon et al., 2018; Poh et al., 2018; Ross et al., 2018; Seo et al., 2018; Chen JY et al., 2019; Parate et al., 2020). In a study by Miskon et al. (2018), umbilical cord-derived MSCs were pulsed with EMF for $5 \mathrm{~min}$, and the results indicated an increase in the numbers of monolayer and suspension MSCs by 1.39- and 2.41-fold, respectively, when compared with those of the control group after $5 \mathrm{~d}$ (Miskon et al., 2018). However, the underlying mechanism or EMF frequencies used in this study were not elucidated. In a different study, when BM-derived MSCs were exposed to $15 \mathrm{~Hz}$ of EMF for $8 \mathrm{~h} / \mathrm{d}$, Sun et al. (2009) reported a $59 \%$ and $40 \%$ increase in the viability of MSCs in low- $\left(1000 \mathrm{cells} / \mathrm{cm}^{2}\right)$ and highdensity $\left(3000\right.$ cells $\left./ \mathrm{cm}^{2}\right)$ seeded cultures, respectively. The reason for this could be due to the shortening of the lag phase, causing EMF to enhance the proliferation of MSCs during the exponential phase and leading the cells into the G2/M phase of the cell cycle. Nonetheless, enhanced cellular proliferation served as the outcome of increased DNA synthesis activity. This was made evident when exposing rat- and mousederived MSCs to $50 \mathrm{~Hz}$ of EMF for $4 \mathrm{~h} / \mathrm{d}$ for three consecutive days. It was found that cell viability, DNA synthesis, and the proportion of MSCs in S phase in the EMF group were significantly elevated as compared with the SHAM group (Fan et al., 2015). This finding was also in accordance with a recent study by Bloise et al. (2018) who demonstrated increased DNA synthesis in PEMF-exposed BM-derived MSCs. The continuous expression of several cytokines is required for the process of MSC proliferation and differentiation, and the expression of these cytokines can be modulated by EMF. Some studies have shown that a shortened lag phase of the cell cycle induced by EMF may result in a higher cellular proliferation index, which could be mediated by the increased expression of cytokines (Sun et al., 2009; Zhang et al., 2013; Fan et al., 2015). MSCs exposed to EMF have exhibited the elevated messenger RNA (mRNA) expression of a group of hematopoietic cytokines, namely, macrophage colonystimulating factor (M-CSF), stem cell factor (SCF), leukemia inhibitory factor (LIF), interleukin-7 (IL-7), and IL-11, while the mRNA expression of inflammatory cytokines, stromal cell-derived factor-1 (SDF-1), tumor necrosis factor- $\alpha$ (TNF- $\alpha$ ), and IL- 6 remained unchanged (Fan et al., 2015). These inflammatory cytokines are a part of the soluble factors secreted upon the instigation of signaling pathways activated by BM cells (Harmer et al., 2019). This dynamic event might be due to the pattern and time points of EMF application; it was suggested that the elevation of the aforementioned cytokines might enhance the proliferation of MSCs (Fan et al., 2015). The antigen expression profile of cytokines secreted by MSCs was further analyzed using an antibody fabricated array consisting of 120 antibodies reactive to 120 cytokines, where all MSCs were BM-derived (Park et al., 2009). The array was incubated with the secretion media of cells (from BMand umbilical cord blood (UCB)-derived MSCs), followed by $1.5 \mathrm{~h}$ of incubation with biotin-conjugated antibodies. The hybridized antigen-antibody complexes were detected using streptavidin-conjugated peroxidase. A significant elevation of the signal was observed for six cytokines, IL-6, IL-8, monocyte chemotactic protein-1 (MCP-1), tissue inhibitor of matrix metalloproteinase-2 (TIMP-2), vascular endothelial growth factor (VEGF), and osteoprotegerin (OPG), which was consistent across BM-derived MSC donors of all races, ages, and genders. This profile pattern was found to be similar to that of UCB-derived MSCs, with IL-6 exhibiting the strongest signal. Furthermore, IL-8 with known mitogenic and angiogenic potential showed the highest signal in UCB-derived MSCs. These observations further elucidate the molecular mechanism underlying MSCs (Park et al., 2009). Although the expression levels of M-CSF, SCF, thrombopoietin (TPO), LIF, IL-11, and IL-7 were observed to be significantly upregulated in EMF-exposed MSCs, the causative relationship leading towards MSC proliferation remains unclear. It is also interesting to note that the proliferative effects of EMF on MSCs extend even beyond days after initial exposure, which suggests that the triggered underlying mechanism of action is long-lasting (Tu et al., 2018). The summary of recent studies on the proliferative effects of EMF and PEMF exposure on MSC culture is shown in Table 1 and Fig. 1. 
Table 1 Recent studies on the proliferative effects of EMF/PEMF exposure on MSC cultures

\begin{tabular}{|c|c|c|c|c|c|c|}
\hline Study & $\begin{array}{c}\text { Biological } \\
\text { model }\end{array}$ & $\begin{array}{l}\text { Type of } \\
\text { exposure }\end{array}$ & $\begin{array}{c}\text { Exposure } \\
\text { frequency }(\mathrm{Hz})\end{array}$ & $\begin{array}{c}\text { Exposure } \\
\text { intensity }(\mathrm{mT})\end{array}$ & Duration & Outcome \\
\hline $\begin{array}{l}\text { Jazayeri et al., } \\
2017\end{array}$ & rBM-MSCs & LF-EMF & 15 & 0.2 & $\begin{array}{l}6 \mathrm{~h} / \mathrm{d} \text { for } 5,10, \\
\text { and } 14 \mathrm{~d}\end{array}$ & $\begin{array}{l}\text { Significantly increased MSC } \\
\text { proliferation }\end{array}$ \\
\hline Sun et al., 2009 & hBM-MSCs & PEMF & 15 & & $8 \mathrm{~h} / \mathrm{d}$ & $\begin{array}{l}\text { Expedited the proliferation of } \\
\text { BM-MSCs }\end{array}$ \\
\hline Yan et al., 2010 & hMSCs & ELF-MF & 50 & 20 & & Inhibited the growth of hMSCs \\
\hline $\begin{array}{l}\text { Zhang et al., } \\
2013\end{array}$ & hESCs & LF-EMF & 1,10 , and 50 & 5 & $\begin{array}{l}30 \mathrm{~min} / \mathrm{d} \text { for } 3,5 \text {, } \\
\text { and } 7 \mathrm{~d}\end{array}$ & Increased the proliferation $\mathrm{hESCs}$ \\
\hline $\begin{array}{l}\text { Song et al., } \\
2014 \mathrm{~b}\end{array}$ & rBM-MSCs & SEMF & 15 & 1 & $1 \mathrm{~h} / \mathrm{d}$ & Increased MSC proliferation \\
\hline $\begin{array}{l}\text { Song et al., } \\
\quad 2014 \mathrm{a}\end{array}$ & BM-MSCs & EMF & 15 & 1 & $4 \mathrm{~h} / \mathrm{d}$ & $\begin{array}{l}\text { Expedited the proliferation of } \\
\text { BM-MSCs }\end{array}$ \\
\hline Fan et al, 2015 & rBM-MSCs & ELF-EMF & 50 & 1 & $4 \mathrm{~h} / \mathrm{d}$ & $\begin{array}{l}\text { Increased the proliferation of } \\
\text { MSCs and upregulated } \\
\text { haematopoietic cytokines }\end{array}$ \\
\hline $\begin{array}{l}\text { Marędziak } \\
\text { et al., } 2017\end{array}$ & hAD-MSCs & Static MF & & 0.5 & $24 \mathrm{~h} / \mathrm{d}$ for $7 \mathrm{~d}$ & $\begin{array}{l}\text { Improved the process of } \\
\text { signaling associated with the } \\
\text { proliferation of MSCs }\end{array}$ \\
\hline $\begin{array}{l}\text { Miskon et al., } \\
2018\end{array}$ & hUC-MSCs & EMF & & & $300 \mathrm{~s} / \mathrm{d}$ for $5 \mathrm{~d}$ & $\begin{array}{l}\text { Increased the proliferation of hUC- } \\
\text { MSCs in suspension culture }\end{array}$ \\
\hline $\begin{array}{l}\text { Ehnert et al., } \\
2018\end{array}$ & hAD-MSCs & ELF-PEMF & $16-24$ & $\begin{array}{c}6 \times 10^{-3}- \\
282 \times 10^{-3}\end{array}$ & $\begin{array}{l}7 \mathrm{~min} / \mathrm{d}, 5 \text { times } \\
\text { per week }\end{array}$ & $\begin{array}{l}\text { Significantly increased } \\
\text { mitochondrial activity }\end{array}$ \\
\hline $\begin{array}{l}\text { Ferroni et al., } \\
2018\end{array}$ & MSCs & PEMF & & & $1,3,15$, and $30 \mathrm{~d}$ & $\begin{array}{l}\text { Significantly increased MSC } \\
\text { proliferation }\end{array}$ \\
\hline Seo et al., 2018 & BM-MSCs & PEMF & 50 & 1 & $\begin{array}{l}1 \mathrm{~h} / \mathrm{d} \text { for } 5,7 \text {, } \\
\text { and } 10 \mathrm{~d}\end{array}$ & $\begin{array}{l}\text { Slight changes though not } \\
\text { significant }\end{array}$ \\
\hline $\begin{array}{l}\text { Bloise et al., } \\
2018\end{array}$ & hBM-MSCs & PEMF & 75 & 2 & $\begin{array}{c}10 \mathrm{~min} / \mathrm{d} \text { for } \\
1-15 \mathrm{~d}\end{array}$ & $\begin{array}{l}\text { Significantly increased MSC } \\
\text { proliferation }\end{array}$ \\
\hline Poh et al., 2018 & hAD-MSCs & ELF-PEMF & 26 & & $3 \mathrm{~d}$ & No significant changes \\
\hline $\begin{array}{l}\text { Ross et al., } \\
2018\end{array}$ & hMSCs & ELF-EMF & 5 & 0.4 & $\begin{array}{l}20 \mathrm{~min} / \mathrm{d}, 3 \text { times } \\
\text { per week } \\
\text { for } 2 \text { weeks }\end{array}$ & $\begin{array}{l}\text { Slight changes though not } \\
\text { significant }\end{array}$ \\
\hline Tu et al., 2018 & rBM-MSCs & SEMF & 15 & 1 & $4 \mathrm{~h} / \mathrm{d}$ & $\begin{array}{l}\text { Significantly increased MSC } \\
\text { proliferation }\end{array}$ \\
\hline $\begin{array}{l}\text { Zhang et al., } \\
2018\end{array}$ & BM-MSCs & EMF & $\begin{array}{r}7.5,15,30 \\
50, \text { and } 75\end{array}$ & 1 & $24 \mathrm{~h}$ & $\begin{array}{l}\text { Increased MSC migration but no } \\
\text { proliferative changes }\end{array}$ \\
\hline $\begin{array}{l}\text { Chen et al., } \\
\text { 2019a }\end{array}$ & rBM-MSCs & SEMF & 15 & 1 & $4 \mathrm{~h} / \mathrm{d}$ for $7 \mathrm{~d}$ & $\begin{array}{l}\text { Significantly increased MSC } \\
\text { proliferation }\end{array}$ \\
\hline $\begin{array}{l}\text { Parate et al., } \\
2020\end{array}$ & MSCs & PEMF & 15 & 2 & $30 \mathrm{~min}$ & No significant changes \\
\hline
\end{tabular}

EMF: electromagnetic field; PEMF: pulsed EMF; MSC: mesenchymal stem cell; BM: bone marrow; rBM-MSCs: rat BM-MSCs; hBM-MSCs: human BM-MSCs; hMSCs: human MSCs; hESCs: human epidermal stem cells; hUC-MSCs: human umbilical cord-derived MSCs; hADMSCs: human adipose-derived MSCs; LF: low-frequency; ELF: extremely LF; MF: magnetic field; SEMF: sinusoidal EMF.

It was proposed that PEMF exposure may have triggered the release of free ions such as potassium ion $\left(\mathrm{K}^{+}\right)$and calcium ion $\left(\mathrm{Ca}^{2+}\right)$ from the smooth endoplasmic reticulum (ER), which can subsequently affect the activity of activated $\mathrm{K}^{+}$channels, leading to enhanced cellular progression from G1 to $\mathrm{S}$ phases (Jazayeri et al., 2017). For instance, $\mathrm{Ca}^{2+}$ has been regarded as an important second messenger in a given cell, as it regulates a plethora of signal transduction in critical processes, such as adenosine triphosphate
(ATP) synthesis, apoptosis, cellular motility, gene expression, and proliferation. In a study it was demonstrated that intracellular $\mathrm{Ca}^{2+}$ signaling mediates insulinlike growth factor-1 (IGF-1)-induced proliferation in MSCs (Wu et al., 2020). As non-excitable cells, $\mathrm{Ca}^{2+}$ oscillations in MSCs are typically initiated by the upregulation of inositol-1,4,5-triphosphate receptor 2 $\left(\mathrm{IP}_{3} \mathrm{R} 2\right)$ and sarco/endoplasmic reticulum $\mathrm{Ca}^{2+}$-ATPase 3 (SERCA3), resulting in $\mathrm{Ca}^{2+}$ release from the ER. It was outlined that $\mathrm{Ca}^{2+}$ oscillations may increase the 


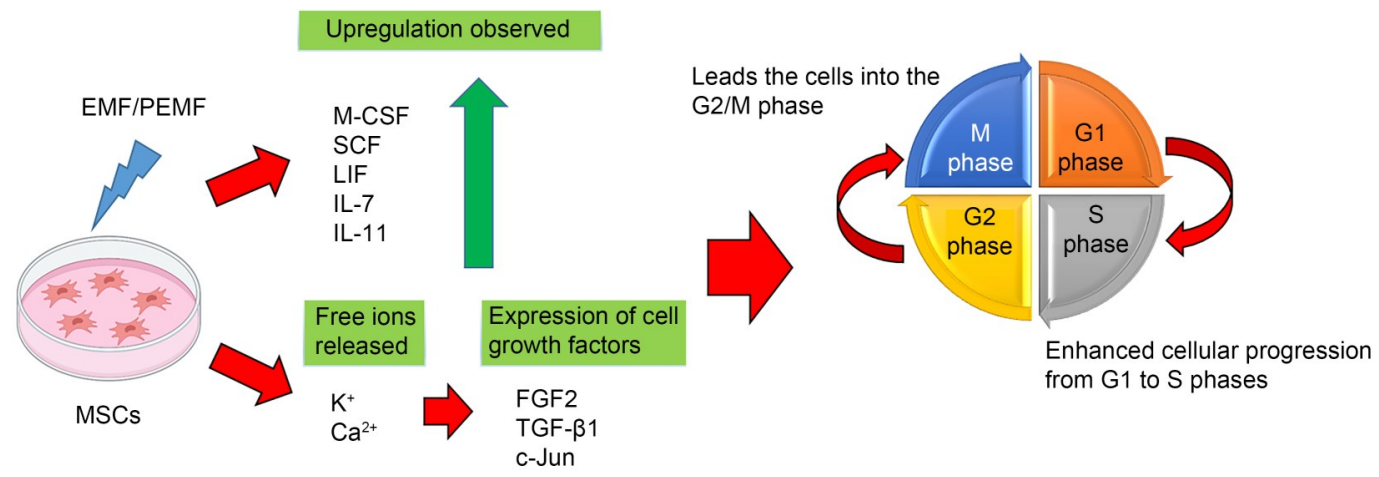

Fig. 1 EMF triggered the elevated mRNA expression of a group of hematopoietic cytokines that might enhance the proliferation of MSCs. EMF: electromagnetic field; mRNA: messenger RNA; MSC: mesenchymal stem cell; PEMF: pulsed EMF; M-CSF: macrophage colony-stimulating factor; SCF: stem cell factor; LIF: leukemia inhibitory factor; IL: interleukin; FGF-2: fibroblast growth factor-2; TGF- $\beta 1$ : transforming growth factor- $\beta 1$.

levels of cyclins A and E that regulate cell cycle progression and proliferation (Hanna et al., 2017). Moreover, it was reported that elevated levels of extracellular $\mathrm{Ca}^{2+}$ may also directly promote MSC proliferation through the induced expression of FGF-2 and transforming growth factor- $\beta 1$ (TGF- $\beta 1$ ), as well as cell cycle regulator c-Jun (Lee et al., 2018). Given that cellular exposure to EMF has been shown to dramatically increase $\mathrm{Ca}^{2+}$ influx though enhanced presynaptic calcium channel expression, the proposed notion that the increased proliferation of EMF-exposed MSCs is mediated by the alterations of its $\mathrm{Ca}^{2+}$ current is well supported (Sun et al., 2016). Some investigators also proposed the function of signal transduction pathway as responsible for the proliferative effects of EMF exposure on MSC cultures. In their study, Fan et al. (2015) proposed that the induced FGF-2 may inhibit cellular senescence and promote cellular proliferation via the phosphoinositide 3-kinase (PI3K)/serine-threonine kinase (AKT)-mouse double minute 2 (MDM2) signaling pathway. This notion is in agreement with recent studies that proposed the involvement of $\mathrm{PI} 3 \mathrm{~K} / \mathrm{AKT}$ signaling as one of key players in the maintenance of self-renewal and stemness of MSCs (Fong et al., 2007; Schaefer et al., 2020). The in-depth explanation regarding EMF interaction with biological cells may open a new perspective, in particular in the application of EMF to MSCs, as depicted in Fig. 2.

Though multiple studies have provided evidence on the proliferative effects of EMF on MSC cultures, some papers presented contradicting findings (Yan et al., 2010). These discrepancies are not immediately clear, though some scholars described that the effects of EMF depend on the cell type, cell state, frequency, amplitude, and exposure time (Ivancsits et al., 2005; Zhang et al., 2007; Song et al., 2014b). Prolonged EMF exposure, for instance, could negatively impact the viability and proliferation of MSCs. This has been made evident by Marmotti et al. (2018) who investigated the optimal exposure duration of EMF onto MSC culture per day and the longest time period of exposure it could withstand before exhibiting a decreasing trend in cell survival. Additionally, this study reaffirms the findings of earlier works that had also provided evidence supporting that the observed proliferative effects of MSCs post-EMF exposure are greatly time duration-dependent (Song et al., 2014b).

\subsection{Effects of EMF on the differentiation of MSCs}

Another important goal of the EMF exposure strategy is to positively reinforce the differentiative capability of MSCs. As mentioned previously, EMF therapy has been used to treat a broad range of diseases, such as non-union bone fractures, osteoporosis, and pseudarthrosis, as well as for cartilage and tendon repair (Shupak et al., 2003; Assiotis et al., 2012; Zhou et al., 2012). Although the exact mechanism by which EMF stimulation induces lineage commitment within MSCs remains inconclusive, it has been well established that Runt-related transcription factor 2 (Runx2)/ core-binding factor $\alpha 1(\mathrm{Cbfal})$ and osterix $(\mathrm{Sp} 7)$ serve as predominant transcription factors that drive MSC osteogenic differentiation, while SRY-box transcription 9 (Sox 9$)$ and the modulation of the $\mathrm{Wnt} / \beta$-catenin signaling pathway control chondrogenesis in cultures (Ross et al., 2015). Interestingly, the expression levels 


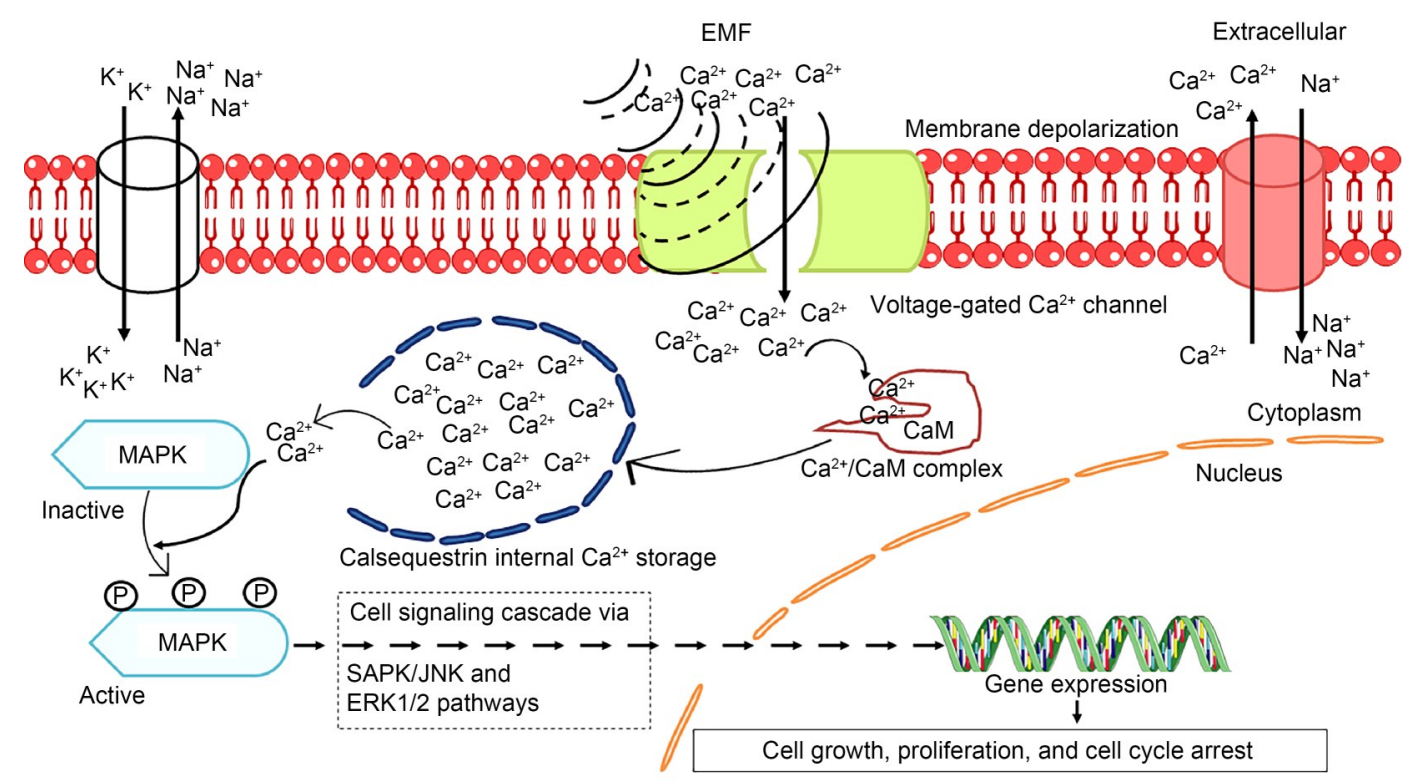

Fig. 2 Overview of cellular processes during exposure to EMF. EMF: electromagnetic field; MAPK: mitogen-activated protein kinase; SAPK: stress-activated protein kinase; JNK: c-Jun N-terminal kinase; ERK: extracellular signalregulated kinase; CaM: calmodulin.

of osteoblastic marker genes Runx2 and osteocalcin $(O c n)$ were significantly elevated when the MSCs were subjected to daily PEMF exposure when compared with unexposed cultures prior to transitioning to the mineralization phase between Day 10 and Day 14 (Jazayeri et al., 2017). Other studies have also highlighted the phosphorylation of the extracellular signalregulated kinase 1/2 (ERK1/2) and protein kinase A (PKA) signaling pathways in osteogenesis induction by EMF as a result of elevated cyclic adenosine monophosphate (cAMP) levels. Yong et al. (2016) have shown that pretreatment of MSCs with ERK and PKA inhibitors prior to PEMF exposure resulted in the significant inhibition of the induction of osteogenic markers Runx2, bone morphogenetic protein 2 (BMP2), and $O c n$. In a different study, increased osteogenic differentiation through PEMF exposure was accompanied by the strong expression of osteogenic markers including osteonectin, osteopontin, collagen I, and collagen III. It is noteworthy that alkaline phosphatase (ALP) activity was observed to be upregulated followed by the downregulation of MSC markers cluster of differentiation 90 (CD90), CD73, and CD105 in cells (Kim et al., 2015).

In other examples, EMF was employed for cartilage and tendon repair via the chondrogenic and tenogenic differentiation potentials of MSCs, respectively, with varying degrees of success (Haddad et al.,
2007; de Girolamo et al., 2013). Although several studies observed little to no effect of EMF stimulation during chondrification (Mayer-Wagner et al., 2011; Esposito et al., 2013; Ongaro et al., 2015), Parate et al. (2017) showed that brief single exposure of low-amplitude EMF worked best at inducing the chondrogenesis of MSCs. Obvious differences in the stimulation protocols or techniques used by different research groups may explain these inconsistent and conflicting results. Past studies had longer exposure time (hours per day for days or weeks), whereas Parate et al. (2017) applied EMF only once for $10 \mathrm{~min}$ for the chondrogenic stimulation of BM-derived MSCs. The major players implicated in the chondrogenic developmental process are $\mathrm{Ca}^{2+}$ influx and the mechanosensitive transient receptor potential (TRP) channels TRPC1 and TRPV4 (Parate et al., 2017). With respect to the in vitro tendon commitment of umbilical cordderived MSCs, exposure to PEMF for different periods leads to the increased syntheses of scleraxis and collagen type I. Moreover, an increase in the amounts of IL-10 and VEGF throughout the culture suggested the possibility of an indirect mechanism of tenogenic activation initiated by EMF for the healing and repair of tendons (Marmotti et al., 2018).

EMF exposure may also influence the differentiation of MSCs into non-mesodermal lineage cells, 
such as neurons and astrocyte cells (Jeong et al., 2017; Asadian et al., 2021). At an intensity of $400 \mu \mathrm{T}$, BMMSC can reach the highest degree of neuronal differentiation for EMF groups with sinusoidal frequencies of 50 and $75 \mathrm{~Hz}$, while astrocytes are frequencydependent, and $75 \mathrm{~Hz}$ square and $75 \mathrm{~Hz}$ EMF produce the most significant effect on the differentiation of BM-MSC to astrocytes (Asadian et al., 2021). In another study of astrocytes, ELF-EMF at $50 \mathrm{~Hz}$ upregulated sirtuin1 (SIRT1), promoting the astrocytic differentiation of human BM-MSCs (hBM-MSCs) through the regulation of downstream molecules of SIRT1 (HES1 and MASH1) (Jeong et al., 2017).

In addition to the use of PEMF, in bone tissue engineering applications, the incorporation of PEMF into titanium dioxide $\left(\mathrm{TiO}_{2}\right)$ surfaces cultured with hBM-MSCs in osteogenic medium also showed a good combination. This fusion is evidenced by the increased expression of early- and end-stage osteogenic genes and proteins (such as ALP, COL-I, OCN, and
$O P N$ ) in PEMF-stimulated hBM-MSCs. Interestingly, the fact that osteogenesis significantly increased was further supported by the findings that cells treated with $\mathrm{PEMF} / \mathrm{TiO}_{2}$ produced secretions into media containing higher amounts of BMP2, decorin (DCN), and collagen type I, compared with untreated controls (Bloise et al., 2018). Table 2 shows a collection of studies on the effects of EMFs on the differentiation capacity of MSCs, and Fig. 3 depicts the effects of EMF on the differentiation of MSCs.

\subsection{Effects of EMF on the immunoregulatory and regenerative activity of MSCs}

MSCs exhibit potent immunomodulatory activity on almost all kinds of immune cells. This activity allows MSCs to act as an attractive tool for ameliorating autoimmune diseases (de Bari, 2015). For instance, the intravenous injection of MSCs derived from umbilical cord blood could constitute a therapeutic option for patients with rheumatoid arthritis (RA) through the

Table 2 Recent studies on the effects of EMF exposure on MSC differentiation

\begin{tabular}{|c|c|c|c|c|c|c|}
\hline Study & $\begin{array}{l}\text { Biological } \\
\text { model }\end{array}$ & $\begin{array}{l}\text { Type of } \\
\text { exposure }\end{array}$ & $\begin{array}{c}\text { Exposure } \\
\text { frequency }(\mathrm{Hz})\end{array}$ & $\begin{array}{c}\text { Exposure } \\
\text { intensity }(\mathrm{mT})\end{array}$ & Duration & Outcome \\
\hline $\begin{array}{l}\text { Mayer-Wagner } \\
\text { et al., } 2011\end{array}$ & hMSCs & $\begin{array}{r}\text { Homogeneous } \\
\text { SELF-MFs }\end{array}$ & & 5 & 3 weeks & $\begin{array}{l}\text { EMF might be a way to stimulate } \\
\text { and maintain the } \\
\text { chondrogenesis of hMSCs }\end{array}$ \\
\hline $\begin{array}{l}\text { Esposito et al., } \\
2013\end{array}$ & WJ-MSCs & PEMF & $75( \pm 5 \%)$ & $1.8-3.0$ & $8 \mathrm{~h} / \mathrm{d}$ for $21 \mathrm{~d}$ & $\begin{array}{l}\text { Significant early differentiation } \\
\text { of WJ-MSCs into cartilaginous } \\
\text { tissue }\end{array}$ \\
\hline $\begin{array}{l}\text { Ongaro et al., } \\
2015\end{array}$ & $\begin{array}{l}\text { BM-MSC } \\
\text { and AD- } \\
\text { MSCs }\end{array}$ & PEMF & 75 & 1500 & & $\begin{array}{l}\text { PEMF stimulates the osteogenic } \\
\text { differentiation of both BM-MSCs } \\
\text { and AD-MSCs }\end{array}$ \\
\hline Kim et al., 2015 & hBM-MSCs & EMF & 45 & 1 & $\begin{array}{l}2 \times \text { every } 8 \mathrm{~h} / \mathrm{d} \\
\quad \text { for } 7 \mathrm{~d}\end{array}$ & $\begin{array}{l}\text { Significantly increased } \\
\text { osteogenic differentiation }\end{array}$ \\
\hline Ross et al., 2015 & $\begin{array}{l}\text { hSSCs/ } \\
\text { BMSCs }\end{array}$ & LF-EMF & & & & $\begin{array}{l}\text { Significantly enhanced osteogenic } \\
\text { and chondrogenic } \\
\text { differentiation of hSSCs/BMSCs }\end{array}$ \\
\hline $\begin{array}{l}\text { Yong et al., } \\
2016\end{array}$ & Rat MSCs & SEMF & 15 & 1 & $8 \mathrm{~h} / \mathrm{d}$ for $6 \mathrm{~d}$ & $\begin{array}{l}\text { EMF promoted the osteogenic } \\
\text { differentiation of sinus MSC }\end{array}$ \\
\hline $\begin{array}{l}\text { Parate et al., } \\
2017\end{array}$ & MSCs & PEMF & 15 & 2 & $10 \mathrm{~min} / \mathrm{d}$ & $\begin{array}{l}\text { Significantly increased } \\
\text { chondrogenic differentiation }\end{array}$ \\
\hline $\begin{array}{l}\text { Jazayeri et al., } \\
2017\end{array}$ & MSCs & PEMF & 15 & 0.2 & $6 \mathrm{~h} / \mathrm{d}$ for $10 \mathrm{~d}$ & $\begin{array}{l}\text { Significantly increased } \\
\text { osteogenic differentiation }\end{array}$ \\
\hline $\begin{array}{l}\text { Jeong et al., } \\
2017\end{array}$ & hBM-MSCs & ELF-EMF & 50 & 1 & $12 \mathrm{~d}$ & $\begin{array}{l}\text { Significantly promoted astrocytic } \\
\text { differentiation }\end{array}$ \\
\hline $\begin{array}{l}\text { Bloise et al., } \\
2018\end{array}$ & hBM-MSCs & PEMF & 75 & 2 & $\begin{array}{l}10 \mathrm{~min} / \mathrm{d} \\
\quad \text { for } 7 \text { and } 28 \mathrm{~d}\end{array}$ & $\begin{array}{l}\text { Significantly increased } \\
\text { osteogenic differentiation }\end{array}$ \\
\hline $\begin{array}{l}\text { Asadian et al., } \\
2021\end{array}$ & BM-MSCs & SEMF & 50 and 75 & 0.4 & $1 \mathrm{~h} / \mathrm{d}$ for $7 \mathrm{~d}$ & $\begin{array}{l}\text { Significantly increased } \\
\text { differentiation to neurons and } \\
\text { astrocyte cells }\end{array}$ \\
\hline
\end{tabular}

EMF: electromagnetic field; PEMF: pulsed EMF; MSC: mesenchymal stem cell; hMSCs: human MSCs; WJ-MSCs: Wharton's Jelly-derived MSCs; AD-MSCs: adipose-derived MSCs; BM: bone marrow; hBM-MSCs: human BM-MSCs; hSSCs/BMSCs: human skeletal stem cells/ bone marrow stem cells; LF: low-frequency; ELF: extremely LF; SELF-MFs: sinusoidal ELF magnetic fields; SEMF: sinusoidal EMF. 


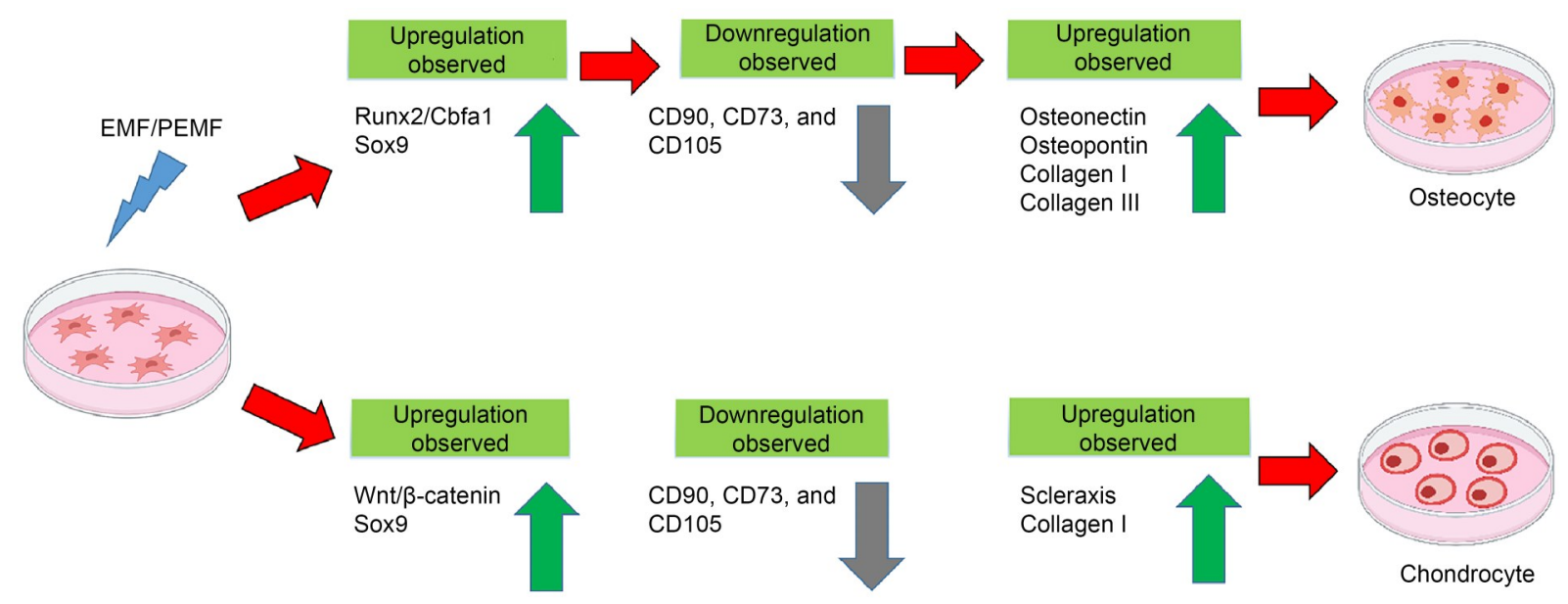

Fig. 3 Overview of the effects of EMF on the differentiation of MSCs. EMF: electromagnetic field; MSCs: mesenchymal stem cells; Runx2: runt-related transcription factor 2; Cbfa1: core-binding factor $\alpha 1$; Sox9: SRY-box transcription 9; CD: cluster of differentiation.

reduction of pro-inflammatory cytokine levels, such as those of IL-1 $\beta$, IL-6, IL-8, and TNF- $\alpha$ (Park et al., 2018). MSCs activated by lipopolysaccharide (LPS) and exposed to $5.1 \mathrm{~Hz}$ EMF for $5 \mathrm{~min}$ showed the declined production of pro-inflammatory molecules (IL$1 \mathrm{~b}$, IL-6, and IL-17A) and enhanced secretions of antiinflammatory cytokines (IL-3, IL-4, and IL-10) (Ross et al., 2019).

It was recently shown that EMF affects tissue regeneration and wound healing processes (Pesce et al., 2013; Geng et al., 2014). This includes reductions in total healing time, recurrence rate, wound size, as well as enhancement of the re-epithelialization process (Ieran et al., 1990; Ross and Harrison, 2013; Cheing et al., 2014). Zhang et al. (2018) employed different EMF frequencies (range of 7.5-75 Hz) to evaluate the migration activity of MSCs. They reported that EMF promoted MSC migration by accumulating intracellular $\mathrm{Ca}^{2+}$. The activation of focal adhesion kinase (FAK) leads to the formation of focal contacts and Rho GTPase, which mediates the organization of the cytoskeleton via the FAK/Rho GTPase signaling pathways. Moreover, Wang et al. (2014) investigated the effects of EMF on rat osteoblast adhesion on implant surfaces (titanium), and found that EMF stimulation significantly increased the initial osteoblast adhesion to these surfaces. Furthermore, EMF promotes directional migration and adhesion for a variety of cells involved in regenerative medicine, tissue engineering, and wound healing (Ross, 2017).

\section{Cytotoxic and genotoxic effects of EMF on MSCs}

Safety and efficacy are two of the major facets of clinical-based trials and continue to serve as the obligatory criteria for any form of therapy intended for mass consumption (Bernardo and Fibbe, 2012; Wang et al., 2013; Freitag et al., 2016). EMF and its impacts on MSCs are a good example of emerging solutions for many ailments. Because of the negative connotations revolving around EMF and the effects of radiation, concerns have been raised regarding its usage at the therapeutic level (D'Angelo et al., 2015). To determine whether EMF is either dangerous or harmless, certain parameters such as amplitude, frequency, and exposure time are needed to be considered (Carpenter and Ayrapetyan, 1994; Miskon and Uslama, 2011). Two studies have shown that EMF exposure within a specified range does not cause any cytotoxic effects in MSCs. In the first, Kim et al. (2015) reported no morphological changes or necrosis to human BMderived MSCs during osteogenesis upon exposure to $45 \mathrm{~Hz}$ of EMF (16 h/d with intervals) for a duration of $7 \mathrm{~d}$. Furthermore, the lactate dehydrogenase (LDH) activity of MSCs treated with EMF did not increase, suggesting no damage to the cell membrane due to radio sensitization. Another study conducted by Ross et al. (2018) tested the cyto/genotoxic activity of $5 \mathrm{~Hz}$, $0.4 \mathrm{mT}$ ELF-EMF on human MSCs for $20 \mathrm{~min} / \mathrm{d}$ three times a week for two weeks. Their experiment involved cell viability and proliferation assays along with 
karyotype analysis, and the results showed no evidence of cytotoxicity or genotoxic chromosomal breaks in the nucleus of MSCs after EMF exposure. Nevertheless, the abovementioned findings are limited to EMF exposure within a small range of frequency, and the influence of other contributing variables, namely amplitude and length of exposure, remains to be investigated. Thus, the critical evaluation and optimization of the said parameters are vital prior to introducing EMF in the clinical therapy of MSCs.

\section{Current strategies to trigger the proliferation of MSCs}

During the clinical administration of MSCs, certain features such as suitable dose, proper routes of delivery, and correct functionalities of cells within the system are essential to ensure the most effective form of therapy (Kurtz, 2008; Golpanian et al., 2016; Florea et al., 2017). Nonetheless, primary human MSCs do not grow indefinitely in culture; hence an adequate repertoire of MSCs is necessary prior to conducting clinicalbased transplantations. To achieve this aim, previous studies have performed the in-depth assessment and standardization of many aspects of MSC culture, including the type of culture media used, cell-plating density, addition of growth factors, and selection of appropriate culture flasks (Sotiropoulou et al., 2006; Bernardo et al., 2007; Ikebe and Suzuki, 2014). Regardless, it is worth mentioning that supplementation techniques and culture conditions are two of the most extensively studied areas on MSCs. The term culture conditions/environments here refer strictly to the physicochemical components of cell culture (temperature, $\mathrm{pH}$, oxygen concentration, etc.). Thus, from this point onwards, focus will be given primarily to studies on these two parameters.

The proliferation and survival of MSCs depend heavily on the type and amount of nutrients contained in the culture media, which has been widely investigated in a number of recent studies (Solchaga et al., 2005; Choi et al., 2008; Tamama et al., 2010; Sun et al., 2013). The basic FGF (b-FGF) is one of the key ingredients for MSC culture due to its varied effector actions including the enhancement of proliferation and immunosuppressive activity of MSCs (Bianchi et al., 2003; Sotiropoulou et al., 2006; Ikebe and
Suzuki, 2014). Besides b-FGF, other factors that may further ameliorate the expansion of MSCs are IGF (Doucet et al., 2005), EGF (Tamama et al., 2010), PDGF (Kumar et al., 2010), IL-6 (Pricola et al., 2009), and TGF- $\beta$ (Doucet et al., 2005; Ng et al., 2008). However, whether MSCs could maintain their stem cell phenotype and differentiation potential following long-term culture with these supplements remains to be conclusive, since many of these studies were carried out within a short period of time. Some factors promoting cell division may elicit unwanted bystander impacts that could act on certain signaling pathways. The mitogen PDGF, for instance, could indirectly prevent the differentiation of MSCs (Pytlík et al., 2011). Furthermore, it has been shown that the addition of b-FGF could trigger a dose-dependent upregulation of histocompatibility markers, especially that of class I molecules (Sotiropoulou et al., 2006). This will inevitably render the cultured MSCs more prone to rejection during clinical transfer as a result of immune incompatibility.

When it comes to the viability and multipotency of stem cells, local niche conditions are deemed highly influential. Likewise, MSCs are sensitive to various types of physicochemical and mechanical changes in their microenvironment (Winer et al., 2009; Kelly and Jacobs, 2010). With regard to this matter, several studies have highlighted oxygen concentration as a major determinant of stem cell proliferation, as well as the maintenance of pluripotency (Ezashi et al., 2005; Ma et al., 2009; Widowati et al., 2014). In the case of MSCs, it was found that the low-oxygen (the volume fraction of $\mathrm{O}_{2}$ is $2.5 \%$ ) condition significantly increased the cell proliferation kinetics with reduced population doubling time (Widowati et al., 2014). This is in accordance with the observation made by Haque et al. (2013), which concluded that a hypoxic environment can greatly improve growth kinetics, genetic stability, and the expression of chemokine receptors during in vitro expansion, and eventually increase efficiency of MSC-based regenerative therapies. Hence, by manipulating the oxygenic settings of cells, the quantity and quality of MSCs may be improved for clinical use. One drawback to this approach is that the role of oxygen tension during MSC differentiation is largely influenced by the applied cell isolation technique, the presence of growth factors, and other physiologic requirements. Moreover, substantial discrepancies 
exist in the differentiation capacities of hypoxic MSCs derived from in vitro and in vivo experimentations (Ma et al., 2009). Although seemingly promising, further laboratory validations are vital for a complete understanding of the effects of oxygen content on driving the underlying molecular mechanism of cell specialization.

Apart from oxygen concentration, mechanical strain and vibrations have also been associated with the modulation of MSCs, especially during cellular proliferation and differentiation. The response of MSCs to physical stimulation is influenced by the amount of frequency, acceleration, and duration used (McClarren and Olabisi, 2018). Low-intensity vibration (LIV) is usually applied to cells within the range of 10 and $800 \mathrm{~Hz}$, which enhances their structure, leading to increased cellular proliferation and differentiation (Touchstone et al., 2019). When compared with the control group, the application of LIV on MSCs (about twice daily for $20 \mathrm{~min}$ at $90 \mathrm{~Hz}$ ) increased the cell doubling rate by $28 \%$, reduced the activity of $\beta$ galactosidase by about $39 \%$ in (related to senescence), and improved the rates of osteogenesis and adipogenesis at earlier passages (Bas et al., 2020). The application of LIV may also be beneficial for restoring the diminished proliferation of MSCs (Touchstone et al., 2019). Notwithstanding these findings, the reactivity of MSCs to mechanical loading appears to lack consistency and gave varying results in different culture environments, either in tissue culture plastics or two/ three-dimensional scaffolds (McClarren and Olabisi, 2018).

\section{Conclusions}

Finding novel treatments to promote MSC proliferation and differentiation without cytotoxic and genotoxic effects can bring new ideas to the field of regenerative medicine and tissue engineering. With the recent advancement of cell culture methods and the emergence of specialized bioreactors, EMF therapy is clearly a promising method to further promote the proliferation and differentiation of MSCs. In the past, EMF therapy was successfully used as an effective, non-invasive approach for the treatment of bone diseases. As highlighted by the present review, various studies have demonstrated the positive effects of EMF of $0.2-5.0 \mathrm{mT}$ and $15-75 \mathrm{~Hz}$ on the proliferation and differentiation of MSCs for various treatment time. The results of these studies also underscored that EMF could not only support expansion but also induce the commitment of MSCs into osteogenic, chondrogenic, and tenogenic lineages. Although EMF exposure has shown great potential as a novel strategy for the clinical expansion of MSCs, the further examination of the core properties of EMF is necessary to pinpoint the unique range of exposure that could enhance the proliferation of MSCs while maintaining their differentiation potential and stem cell phenotype.

\section{Acknowledgments}

This research was supported by the Malaysian Fundamental Research Grant Scheme (No. FRGS/2/2013/SKK01/ UPNM/02/1). The authors fully acknowledge the Ministry of Higher Education (MOHE) Malaysia for the funding approval and allowing this important research to come to fruition. The authors would like to thank the staff and students from the Stem Cell Research Laboratory, Genetics and Regenerative Medicine Research Centre, and Immunology Unit, Department of Pathology in Universiti Putra Malaysia for their knowledge and expertise. We also wish to acknowledge the librarian from the National Defence University of Malaysia for assistance in the provision of literary materials.

\section{Author contributions}

Haslinda Abdul HAMID drafted and wrote the manuscript with contribution from Azizi MISKON, Rajesh RAMASAMY, Vahid Hosseinpour SARMADI, and Vivek PRASAD. Azizi MISKON conceived the original idea. All authors have read and approved the final manuscript, and therefore, take responsibility for the integrity and security of the data.

\section{Compliance with ethics guidelines}

Haslinda Abdul HAMID, Vahid Hosseinpour SARMADI, Vivek PRASAD, Rajesh RAMASAMY, and Azizi MISKON declare that they have no conflict of interest.

This article does not contain any studies with human or animal subjects performed by any of the authors.

\section{References}

Aggarwal S, Pittenger MF, 2005. Human mesenchymal stem cells modulate allogeneic immune cell responses. Blood, 105(4):1815-1822.

https://doi.org/10.1182/blood-2004-04-1559

Alt EU, Senst C, Murthy SN, et al., 2012. Aging alters tissue resident mesenchymal stem cell properties. Stem Cell Res, 8(2):215-225.

https://doi.org/10.1016/j.scr.2011.11.002.

Ang XM, Lee MHC, Blocki A, et al., 2014. Macromolecular 
crowding amplifies adipogenesis of human bone marrowderived mesenchymal stem cells by enhancing the pro-adipogenic microenvironment. Tissue Eng Part A, 20(5-6):966-981.

https://doi.org/10.1089/ten.TEA.2013.0337

Asadian N, Jadidi M, Safari M, et al., 2021. EMF frequency dependent differentiation of rat bone marrow mesenchymal stem cells to astrocyte cells. Neurosci Lett, 744:135587. https://doi.org/10.1016/j.neulet.2020.135587

Assiotis A, Sachinis NP, Chalidis BE, 2012. Pulsed electromagnetic fields for the treatment of tibial delayed unions and nonunions. A prospective clinical study and review of the literature. J Orthop Surg Res, 7:24. https://doi.org/10.1186/1749-799X-7-24

Barry FP, Murphy JM, English K, et al., 2005. Immunogenicity of adult mesenchymal stem cells: lessons from the fetal allograft. Stem Cells Dev, 14(3):252-265. https://doi.org/10.1089/scd.2005.14.252

Bas G, Loisate S, Hudon SF, et al., 2020. Low intensity vibrations augment mesenchymal stem cell proliferation and differentiation capacity during in vitro expansion. Sci Rep, 10:9369. https://doi.org/10.1038/s41598-020-66055-0

Bernardo ME, Fibbe WE, 2012. Safety and efficacy of mesenchymal stromal cell therapy in autoimmune disorders. Ann NY Acad Sci, 1266(1):107-117. https://doi.org/10.1111/j.1749-6632.2012.06667.x

Bernardo ME, Avanzini MA, Perotti C, et al., 2007. Optimization of in vitro expansion of human multipotent mesenchymal stromal cells for cell-therapy approaches: further insights in the search for a fetal calf serum substitute. $J$ Cell Physiol, 211(1):121-130. https://doi.org/10.1002/jcp.20911

Bianchi G, Banfi A, Mastrogiacomo M, et al., 2003. Ex vivo enrichment of mesenchymal cell progenitors by fibroblast growth factor 2. Exp Cell Res, 287(1):98-105. https://doi.org/10.1016/S0014-4827(03)00138-1

Bloise N, Petecchia L, Ceccarelli G, et al., 2018. The effect of pulsed electromagnetic field exposure on osteoinduction of human mesenchymal stem cells cultured on nano- $\mathrm{TiO}_{2}$ surfaces. PLoS ONE, 13(6):e0199046. https://doi.org/10.1371/journal.pone.0199046

Bruno S, Collino F, Deregibus MC, et al., 2013. Microvesicles derived from human bone marrow mesenchymal stem cells inhibit tumor growth. Stem Cells Dev, 22(5):758-771. https://doi.org/10.1089/scd.2012.0304

Butler J, Epstein SE, Greene SJ, et al., 2017. Intravenous allogeneic mesenchymal stem cells for nonischemic cardiomyopathy: safety and efficacy results of a phase II-A randomized trial. Circ Res, 120(2):332-340. https://doi.org/10.1161/CIRCRESAHA.116.309717

Carlsson PO, Svahn MG, 2018. Wharton's jelly derived allogeneic mesenchymal stromal cells for treatment of type $1 \mathrm{di}-$ abetes: study protocol for a double-blinded, randomized, parallel, placebo-controlled trial. Clin Trials Degener Dis, 3(2):32-37.

https://doi.org/10.4103/2542-3975.235141

Carpenter DO, Ayrapetyan S, 1994. Biological Effects of
Electric and Magnetic Fields: Sources and Mechanisms. Academic Press, San Diego, USA, p.1-357.

Cheing GLY, Li XH, Huang L, et al., 2014. Pulsed electromagnetic fields (PEMF) promote early wound healing and myofibroblast proliferation in diabetic rats. Bioelectromagnetics, 35(3):161-169. https://doi.org/10.1002/bem.21832

Chen JY, Tu C, Tang XY, et al., 2019. The combinatory effect of sinusoidal electromagnetic field and VEGF promotes osteogenesis and angiogenesis of mesenchymal stem cell-laden PCL/HA implants in a rat subcritical cranial defect. Stem Cell Res Ther, 10:379. https://doi.org/10.1186/s13287-019-1464-x

Chen MS, Peng J, Xie Q, et al., 2019. Mesenchymal stem cells alleviate moderate-to-severe psoriasis by reducing the production of type I interferon (IFN-I) by plasmacytoid dendritic cells (pDCs). Stem Cells Int, 2019:6961052. https://doi.org/10.1155/2019/6961052

Cheng K, Zou CH, 2006. Electromagnetic field effect on separation of nucleotide sequences and unwinding of a double helix during DNA replication. Med Hypotheses, 66(1):148-153. https://doi.org/10.1016/j.mehy.2005.07.007

Childs BG, Durik M, Baker DJ, et al., 2015. Cellular senescence in aging and age-related disease: from mechanisms to therapy. Nat Med, 21(12):1424-1435. https://doi.org/10.1038/nm.4000

Choi KM, Seo YK, Yoon HH, et al., 2008. Effect of ascorbic acid on bone marrow-derived mesenchymal stem cell proliferation and differentiation. J Biosci Bioeng, 105(6): 586-594. https://doi.org/10.1263/jbb.105.586

Chung YW, Yang HY, Kang SJ, et al., 2021. Allogeneic umbilical cord blood-derived mesenchymal stem cells combined with high tibial osteotomy: a retrospective study on safety and early results. Int Orthop, 45(2):481-488. https://doi.org/10.1007/s00264-020-04852-y

Connick P, Kolappan M, Crawley C, et al., 2012. Autologous mesenchymal stem cells for the treatment of secondary progressive multiple sclerosis: an open-label phase 2a proof-of-concept study. Lancet Neurol, 11(2):150-156. https://doi.org/10.1016/S1474-4422(11)70305-2

D'Angelo C, Costantini E, Kamal MA, et al., 2015. Experimental model for ELF-EMF exposure: concern for human health. Saudi J Biol Sci, 22(1):75-84. https://doi.org/10.1016/j.sjbs.2014.07.006

de Bari C, 2015. Are mesenchymal stem cells in rheumatoid arthritis the good or bad guys? Arthritis Res Ther, 17:113. https://doi.org/10.1186/s13075-015-0634-1

de Francesco F, Ricci G, D'Andrea F, et al., 2015. Human adipose stem cells: from bench to bedside. Tissue Eng Part B Rev, 21(6):572-584. https://doi.org/10.1089/ten.TEB.2014.0608

de Girolamo L, Stanco D, Galliera E, et al., 2013. Low frequency pulsed electromagnetic field affects proliferation, tissue-specific gene expression, and cytokines release of human tendon cells. Cell Biochem Biophys, 66(3):697-708. https://doi.org/10.1007/s12013-013-9514-y 
Doucet C, Ernou I, Zhang YZ, et al., 2005. Platelet lysates promote mesenchymal stem cell expansion: a safety substitute for animal serum in cell-based therapy applications. J Cell Physiol, 205(2):228-236.

https://doi.org/10.1002/jcp.20391

Ehnert S, van Griensven M, Unger M, et al., 2018. Co-culture with human osteoblasts and exposure to extremely low frequency pulsed electromagnetic fields improve osteogenic differentiation of human adipose-derived mesenchymal stem cells. Int J Mol Sci, 19(4):994. https://doi.org/10.3390/ijms19040994

el Omar R, Beroud J, Stoltz JF, et al., 2014. Umbilical cord mesenchymal stem cells: the new gold standard for mesenchymal stem cell-based therapies? Tissue Eng Part B Rev, 20(5):523-544. https://doi.org/10.1089/ten.TEB.2013.0664

Erpicum P, Weekers L, Detry O, et al., 2019. Infusion of thirdparty mesenchymal stromal cells after kidney transplantation: a phase I-II, open-label, clinical study. Kidney Int, 95(3):693-707. https://doi.org/10.1016/j.kint.2018.08.046

Esposito M, Lucariello A, Costanzo C, et al., 2013. Differentiation of human umbilical cord-derived mesenchymal stem cells, WJ-MSCs, into chondrogenic cells in the presence of pulsed electromagnetic fields. In Vivo, 27(4): 495-500.

Ezashi T, Das P, Roberts RM, 2005. Low $\mathrm{O}_{2}$ tensions and the prevention of differentiation of hES cells. Proc Natl Acad Sci USA, 102(13):4783-4788. https://doi.org/10.1073/pnas.0501283102

Fan WX, Qian FH, Ma QL, et al., 2015. $50 \mathrm{~Hz}$ electromagnetic field exposure promotes proliferation and cytokine production of bone marrow mesenchymal stem cells. Int $J$ Clin Exp Med, 8(5):7394-7404.

Ferroni L, Gardin C, Dolkart O, et al., 2018. Pulsed electromagnetic fields increase osteogenetic commitment of MSCs via the mTOR pathway in TNF- $\alpha$ mediated inflammatory conditions: an in-vitro study. Sci Rep, 8:5108. https://doi.org/10.1038/s41598-018-23499-9

Florea V, Rieger AC, DiFede DL, et al., 2017. Dose comparison study of allogeneic mesenchymal stem cells in patients with ischemic cardiomyopathy (the TRIDENT study). Circ Res, 121(11):1279-1290. https://doi.org/10.1161/CIRCRESAHA.117.311827

Fong CY, Richards M, Manasi N, et al., 2007. Comparative growth behaviour and characterization of stem cells from human Wharton's jelly. Reprod BioMed Online, 15(6): 708-718. https://doi.org/10.1016/S1472-6483(10)60539-1

Fossett E, Khan WS, 2012. Optimising human mesenchymal stem cell numbers for clinical application: a literature review. Stem Cells Int, 2012:465259. https://doi.org/10.1155/2012/465259

Freitag J, Bates D, Boyd R, et al., 2016. Mesenchymal stem cell therapy in the treatment of osteoarthritis: reparative pathways, safety and efficacy-a review. BMC Musculoskelet Disord, 17:230. https://doi.org/10.1186/s12891-016-1085-9
Friedenstein AJ, Piatetzky-Shapiro II, Petrakova KV, 1966. Osteogenesis in transplants of bone marrow cells. $J$ Embryol Exp Morphol, 16(3):381-390.

Fung M, Yuan Y, Atkins H, et al., 2017. Responsible translation of stem cell research: an assessment of clinical trial registration and publications. Stem Cell Rep, 8(5):11901201. https://doi.org/10.1016/j.stemcr.2017.03.013

Geng DY, Li CH, Wan XW, et al., 2014. Biochemical kinetics of cell proliferation regulated by extremely low frequency electromagnetic field. BioMed Mater Eng, 24(1):13911397. https://doi.org/10.3233/BME-130943

Gharibi B, Hughes FJ, 2012. Effects of medium supplements on proliferation, differentiation potential, and in vitro expansion of mesenchymal stem cells. Stem Cells Transl Med, 1(11):771-782.

https://doi.org/10.5966/sctm.2010-0031

Golpanian S, Schulman IH, Ebert RF, et al., 2016. Concise review: review and perspective of cell dosage and routes of administration from preclinical and clinical studies of stem cell therapy for heart disease. Stem Cells Transl Med, 5(2):186-191. https://doi.org/10.5966/sctm.2015-0101

Haddad JB, Obolensky AG, Shinnick P, 2007. The biologic effects and the therapeutic mechanism of action of electric and electromagnetic field stimulation on bone and cartilage: new findings and a review of earlier work. $J$ Altern Complement Med, 13(5):485-490. https://doi.org/10.1089/acm.2007.5270

Hanna H, Andre FM, Mir LM, 2017. Electrical control of calcium oscillations in mesenchymal stem cells using microsecond pulsed electric fields. Stem Cell Res Ther, 8:91. https://doi.org/10.1186/s13287-017-0536-z

Haque N, Rahman MT, Abu Kasim NH et al., 2013. Hypoxic culture conditions as a solution for mesenchymal stem cell based regenerative therapy. Sci World J, 2013:632972. https://doi.org/10.1155/2013/632972

Hare JM, DiFede DL, Rieger AC, et al., 2017. Randomized comparison of allogeneic versus autologous mesenchymal stem cells for nonischemic dilated cardiomyopathy: POSEIDON-DCM trial. J Am Coll Cardiol, 69(5):526-537. https://doi.org/10.1016/j.jacc.2016.11.009

Harmer D, Falank C, Reagan MR, 2019. Interleukin-6 interweaves the bone marrow microenvironment, bone loss, and multiple myeloma. Front Endocrinol, 9:788. https://doi.org/10.3389/fendo.2018.00788

Hashimoto Y, Nishida Y, Takahashi S, et al., 2019. Transplantation of autologous bone marrow-derived mesenchymal stem cells under arthroscopic surgery with microfracture versus microfracture alone for articular cartilage lesions in the knee: a multicenter prospective randomized control clinical trial. Regen Ther, 11:106-113. https://doi.org/10.1016/j.reth.2019.06.002

Hu HZ, Yang WB, Zeng QW, et al., 2020. Promising application of pulsed electromagnetic fields (PEMFs) in musculoskeletal disorders. Biomed Pharmacother, 2020(131): 110767. 
https://doi.org/10.1016/j.biopha.2020.110767

Iacobaeus E, Kadri N, Lefsihane K, et al., 2019. Short and long term clinical and immunologic follow up after bone marrow mesenchymal stromal cell therapy in progressive multiple sclerosis - a phase I study. J Clin Med, 8(12): 2102. https://doi.org/10.3390/jcm8122102

Ieran M, Zaffuto S, Bagnacani M, et al., 1990. Effect of low frequency pulsing electromagnetic fields on skin ulcers of venous origin in humans: a double-blind study. J Orthop Res, 8(2):276-282. https://doi.org/10.1002/jor.1100080217

Ikebe C, Suzuki K, 2014. Mesenchymal stem cells for regenerative therapy: optimization of cell preparation protocols. BioMed Res Int, 2014:951512. https://doi.org/10.1155/2014/951512

Ivancsits S, Pilger A, Diem E, et al., 2005. Cell type-specific genotoxic effects of intermittent extremely low-frequency electromagnetic fields. Mutat Res, 583(2):184-188. https://doi.org/10.1016/j.mrgentox.2005.03.011

Jasti AC, Wetzel BJ, Aviles H, et al., 2001. Effect of a wound healing electromagnetic field on inflammatory cytokine gene expression in rats. Biomed Sci Instrum, 37:209-214.

Jazayeri M, Shokrgozar MA, Haghighipour N, et al., 2017. Effects of electromagnetic stimulation on gene expression of mesenchymal stem cells and repair of bone lesions. Cell J, 19(1):34-44. https://doi.org/10.22074/cellj.2017.4870

Jeong WY, Kim JB, Kim HJ, et al., 2017. Extremely lowfrequency electromagnetic field promotes astrocytic differentiation of human bone marrow mesenchymal stem cells by modulating SIRT1 expression. Biosci Biotechnol Biochem, 81(7):1356-1362. https://doi.org/10.1080/09168451.2017.1308243

Jiang RH, Han ZB, Zhuo GS, et al., 2011. Transplantation of placenta-derived mesenchymal stem cells in type 2 diabetes: a pilot study. Front Med, 5(1):94-100. https://doi.org/10.1007/s11684-011-0116-Z

Kaszuba-Zwoinska J, Chorobik P, Juszczak K, et al., 2012. Pulsed electromagnetic field affects intrinsic and endoplasmatic reticulum apoptosis induction pathways in MonoMac6 cell line culture. J Physiol Pharmacol, 63(5): 537-545.

https://doi.org/10.1002/cphy.c110065

Kelly DJ, Jacobs CR, 2010. The role of mechanical signals in regulating chondrogenesis and osteogenesis of mesenchymal stem cells. Birth Defects Res C Embryo Today, 90(1): 75-85. https://doi.org/10.1002/bdrc.20173

Kim MO, Jung H, Kim SC, et al., 2015. Electromagnetic fields and nanomagnetic particles increase the osteogenic differentiation of human bone marrow-derived mesenchymal stem cells. Int J Mol Med, 35(1):153-160. https://doi.org/10.3892/ijmm.2014.1978

Klyushnenkova E, Mosca JD, Zernetkina V, et al., 2005. T cell responses to allogeneic human mesenchymal stem cells: immunogenicity, tolerance, and suppression. $J$ Biomed Sci, 12(1):47-57. https://doi.org/10.1007/s11373-004-8183-7

Kolf CM, Cho E, Tuan RS, 2007. Mesenchymal stromal cells: biology of adult mesenchymal stem cells: regulation of niche, self-renewal and differentiation. Arthritis Res Ther, 9:204. https://doi.org/10.1186/ar2116

Kumar A, Salimath BP, Stark GB, et al., 2010. Plateletderived growth factor receptor signaling is not involved in osteogenic differentiation of human mesenchymal stem cells. Tissue Eng Part A, 16(3):983-993.

http://doi.org/10.1089/ten.tea.2009.0230

Kurtz A, 2008. Mesenchymal stem cell delivery routes and fate. Int J Stem Cells, 1(1):1-7. https://doi.org/10.15283/ijsc.2008.1.1.1

Kurtzberg J, Abdel-Azim H, Carpenter P, et al., 2020. A phase 3 , single-arm, prospective study of remestemcel-1, ex vivo culture-expanded adult human mesenchymal stromal cells for the treatment of pediatric patients who failed to respond to steroid treatment for acute graft-versus-host disease. Biol Blood Marrow Transplant, 26(5):845-854. https://doi.org/10.1016/j.bbmt.2020.01.018

Lee MN, Hwang HS, Oh SH, et al., 2018. Elevated extracellular calcium ions promote proliferation and migration of mesenchymal stem cells via increasing osteopontin expression. Exp Mol Med, 50(11):1-16. https://doi.org/10.1038/s12276-018-0170-6

Lee YS, Sah SK, Lee JH, et al., 2017. Human umbilical cord blood-derived mesenchymal stem cells ameliorate psoriasislike skin inflammation in mice. Biochem Biophys Rep, 9: 281-288.

https://doi.org/10.1016/j.bbrep.2016.10.002

Leng ZK, Zhu RJ, Hou W, et al., 2020. Transplantation of ACE2 ${ }^{-}$mesenchymal stem cells improves the outcome of patients with COVID-19 pneumonia. Aging Dis, 11(2): 216-228. https://doi.org/10.14336/AD.2020.0228

Liang B, Chen JH, Li T, et al., 2020. Clinical remission of a critically ill COVID-19 patient treated by human umbilical cord mesenchymal stem cells: a case report. Medicine (Baltimore), 99(31):e21429. https://doi.org/10.1097/MD.0000000000021429

Lu YR, Yuan Y, Wang XJ, et al., 2008. The growth inhibitory effect of mesenchymal stem cells on tumor cells in vitro and in vivo. Cancer Biol Ther, 7(2):245-251. https://doi.org/10.4161/cbt.7.2.5296

Ma T, Grayson WL, Fröhlich M, et al., 2009. Hypoxia and stem cell-based engineering of mesenchymal tissues. Biotechnol Prog, 25(1):32-42. https://doi.org/10.1002/btpr.128

Maqbool M, Algraittee SJR, Boroojerdi MH, et al., 2020. Human mesenchymal stem cells inhibit the differentiation and effector functions of monocytes. Innate Immun, 26(5): 424-434. https://doi.org/10.1177/1753425919899132

Marędziak M, Tomaszewski K, Polinceusz P, et al., 2017. Static magnetic field enhances the viability and proliferation rate of adipose tissue-derived mesenchymal stem cells potentially through activation of the phosphoinositide 
3-kinase/Akt (PI3K/Akt) pathway. Electromagn Biol Med, 36(1):45-54.

https://doi.org/10.3109/15368378.2016.1149860

Marmotti A, Peretti GM, Mattia S, et al., 2018. Pulsed electromagnetic fields improve tenogenic commitment of umbilical cord-derived mesenchymal stem cells: a potential strategy for tendon repair - an in vitro study. Stem Cells Int, 2018:9048237. https://doi.org/10.1155/2018/9048237

Mayer-Wagner S, Passberger A, Sievers B, et al., 2011. Effects of low frequency electromagnetic fields on the chondrogenic differentiation of human mesenchymal stem cells. Bioelectromagnetics, 32(4):283-290. https://doi.org/10.1002/bem.20633

McClarren B, Olabisi R, 2018. Strain and vibration in mesenchymal stem cells. Int J Biomater, 2018:8686794. https://doi.org/10.1155/2018/8686794

Miskon A, Uslama J, 2011. A preliminary study on magnetic fields effects on stem cell differentiation. In: Osman NAA, Abas WABW, Wahab AKA, et al. (Eds.), 5th Kuala Lumpur International Conference on Biomedical Engineering 2011. IFMBE Proceedings, Vol. 35. Springer, Berlin, Heidelberg, p.805-810. https://doi.org/10.1007/978-3-642-21729-6_197

Miskon A, Abdul Hamid H, Ramasamy R, et al., 2018. Enhanced proliferation potential of human umbilical cord mesenchymal stem cells through suspension induction and electromagnetic field exposure. In: vo van T, Nguyen Le T, Nguyen Duc T (Eds.), 6th International Conference on the Development of Biomedical Engineering in Vietnam (BME6). BME 2017. IFMBE Proceedings, Vol. 63. Springer, Singapore, p.563-566. https://doi.org/10.1007/978-981-10-4361-1_96

Mushahary D, Spittler A, Kasper C, et al., 2018. Isolation, cultivation, and characterization of human mesenchymal stem cells. Cytometry A, 93(1):19-31. https://doi.org/10.1002/cyto.a.23242

$\mathrm{Ng}$ F, Boucher S, Koh S, et al., 2008. PDGF, TGF- $\beta$, and FGF signaling is important for differentiation and growth of mesenchymal stem cells (MSCs): transcriptional profiling can identify markers and signaling pathways important in differentiation of MSCs into adipogenic, chondrogenic, and osteogenic lineages. Blood, 112(2):295-307. https://doi.org/10.1182/blood-2007-07-103697

Ongaro A, Pellati A, Bagheri L, et al., 2014. Pulsed electromagnetic fields stimulate osteogenic differentiation in human bone marrow and adipose tissue derived mesenchymal stem cells. Bioelectromagnetics, 35(6):426-436. https://doi.org/10.1002/bem.21862

Ongaro A, Pellati A, Setti S, et al., 2015. Electromagnetic fields counteract Il-1 $\beta$ activity during chondrogenesis of bovine mesenchymal stem cells. J Tissue Eng Regen Med, 9(12):E229-E238. https://doi.org/10.1002/term.1671

Parate D, Franco-Obregón A, Fröhlich J, et al., 2017. Enhancement of mesenchymal stem cell chondrogenesis with short-term low intensity pulsed electromagnetic fields. Sci Rep, 7:9421. https://doi.org/10.1038/s41598-017-09892-w

Parate D, Kadir ND, Celik C, et al., 2020. Pulsed electromagnetic fields potentiate the paracrine function of mesenchymal stem cells for cartilage regeneration. Stem Cell Res Ther, 11:46. https://doi.org/10.1186/s13287-020-1566-5

Park CW, Kim KS, Bae S, et al., 2009. Cytokine secretion profiling of human mesenchymal stem cells by antibody array. Int J Stem Cells, 2(1):59-68. https://doi.org/10.15283/ijsc.2009.2.1.59

Park EH, Lim HS, Lee S, et al., 2018. Intravenous infusion of umbilical cord blood-derived mesenchymal stem cells in rheumatoid arthritis: a phase Ia clinical trial. Stem Cells Transl Med, 7(9):636-642.

https://doi.org/10.1002/sctm.18-0031

Pesce M, Patruno A, Speranza L, et al., 2013. Extremely low frequency electromagnetic field and wound healing: implication of cytokines as biological mediators. Eur Cytokine Netw, 24(1):1-10. https://doi.org/10.1684/ecn.2013.0332

Pittenger MF, Mackay AM, Beck SC, et al., 1999. Multilineage potential of adult human mesenchymal stem cells. Science, 284(5411):143-147.

https://doi.org/10.1126/science.284.5411.143

Poh PSP, Seeliger C, Unger M, et al., 2018. Osteogenic effect and cell signaling activation of extremely low-frequency pulsed electromagnetic fields in adipose-derived mesenchymal stromal cells. Stem Cells Int, 2018:5402853. https://doi.org/10.1155/2018/5402853

Pricola KL, Kuhn NZ, Haleem-Smith H, et al., 2009. Interleukin6 maintains bone marrow-derived mesenchymal stem cell stemness by an ERK1/2-dependent mechanism. J Cell Biochem, 108(3):577-588.

https://doi.org/10.1002/jcb.22289

Pytlík, Slanař, Stehlík, et al., 2011. Production of clinical grade mesenchymal stromal cells. In: Eberli D (Ed.), Regenerative Medicine and Tissue Engineering-Cells and Biomaterials. InTech, Rijeka, p.145-178. https://doi.org/10.5772/22428

Qiu XS, Li XG, Chen YX, 2020. Pulsed electromagnetic field (PEMF): a potential adjuvant treatment for infected nonunion. Med Hypotheses, 136:109506. https://doi.org/10.1016/j.mehy.2019.109506

Ramasamy R, Krishna K, Maqbool M, et al., 2010. The effect of human mesenchymal stem cell on neutrophil oxidative burst. Malays J Med Health Sci, 6(2):11-17.

Ross CL, 2017. The use of electric, magnetic, and electromagnetic field for directed cell migration and adhesion in regenerative medicine. Biotechnol Prog, 33(1):5-16. https://doi.org/10.1002/btpr.2371

Ross CL, Harrison BS, 2013. Effect of pulsed electromagnetic field on inflammatory pathway markers in RAW 264.7 murine macrophages. J Inflamm Res, 6:45-51. https://doi.org/10.2147/JIR.S40269

Ross CL, Siriwardane M, Almeida-Porada G, et al., 2015. The effect of low-frequency electromagnetic field on human bone marrow stem/progenitor cell differentiation. Stem Cell Res, 15(1):96-108. 
https://doi.org/10.1016/j.scr.2015.04.009

Ross CL, Pettenati MJ, Procita J, et al., 2018. Evaluation of cytotoxic and genotoxic effects of extremely low-frequency electromagnetic field on mesenchymal stromal cells. Glob Adv Health Med, 7:1-7. https://doi.org/10.1177/2164956118777472

Ross CL, Zhou Y, McCall CE, et al., 2019. The use of pulsed electromagnetic field to modulate inflammation and improve tissue regeneration: a review. Bioelectricity, 1(4): 247-259. https://doi.org/10.1089/bioe.2019.0026

Sarmadi VH, Heng FS, Ramasamy R, 2008. The effect of human mesenchymal stem cells on tumour cell proliferation. Med J Malaysia, 63(Suppl A):63-64.

Sarmadi VH, Ahmadloo S, Boroojerdi MH, et al., 2020. Human mesenchymal stem cells-mediated transcriptomic regulation of leukemic cells in delivering anti-tumorigenic effects. Cell Transplant, 29:1-13. https://doi.org/10.1177/0963689719885077

Schaefer T, Steiner R, Lengerke C, 2020. Sox2 and p53 expression control converges in PI3K/AKT signaling with versatile implications for stemness and cancer. Int $J$ Mol Sci, 21(14):4902. https://doi.org/10.3390/ijms21144902

Seo N, Lee SH, Ju KW, et al., 2018. Low-frequency pulsed electromagnetic field pretreated bone marrow-derived mesenchymal stem cells promote the regeneration of crush-injured rat mental nerve. Neural Regen Res, 13(1): 145-153. https://doi.org/10.4103/1673-5374.224383

Seong Y, Moon J, Kim J, 2014. Egr1 mediated the neuronal differentiation induced by extremely low-frequency electromagnetic fields. Life Sci, 102(1):16-27. https://doi.org/10.1016/j.lfs.2014.02.022

Shu L, Niu CM, Li RY, et al., 2020. Treatment of severe COVID-19 with human umbilical cord mesenchymal stem cells. Stem Cell Res Ther, 11:361. https://doi.org/10.1186/s13287-020-01875-5

Shupak NM, Prato FS, Thomas AW, 2003. Therapeutic uses of pulsed magnetic-field exposure: a review. URSI Radio Sci Bull, 2003(307):9-32. https://doi.org/10.23919/URSIRSB.2003.7909506

Solchaga LA, Penick K, Porter JD, et al., 2005. FGF-2 enhances the mitotic and chondrogenic potentials of human adult bone marrow-derived mesenchymal stem cells. $J$ Cell Physiol, 203(2):398-409. https://doi.org/10.1002/jep.20238

Somoza RA, Welter JF, Correa D, et al., 2014. Chondrogenic differentiation of mesenchymal stem cells: challenges and unfulfilled expectations. Tissue Eng Part B Rev, 20(6): 596-608. https://doi.org/10.1089/ten.TEB.2013.0771

Song JS, Hong KT, Kim NM, et al., 2020. Implantation of allogenic umbilical cord blood-derived mesenchymal stem cells improves knee osteoarthritis outcomes: twoyear follow-up. Regen Ther, 14:32-39. https://doi.org/10.1016/j.reth.2019.10.003

Song MY, Zhao DM, Wei S, et al., 2014a. The effect of electromagnetic fields on the proliferation and the osteogenic or adipogenic differentiation of mesenchymal stem cells modulated by dexamethasone. Bioelectromagnetics, 35(7):479-490.

https://doi.org/10.1002/bem.21867

Song MY, Yu JZ, Zhao DM, et al., 2014b. The time-dependent manner of sinusoidal electromagnetic fields on rat bone marrow mesenchymal stem cells proliferation, differentiation, and mineralization. Cell Biochem Biophys, 69(1): 47-54. https://doi.org/10.1007/s12013-013-9764-8

Sotiropoulou PA, Perez SA, Salagianni M, et al., 2006. Characterization of the optimal culture conditions for clinical scale production of human mesenchymal stem cells. Stem Cells, 24(2):462-471. https://doi.org/10.1634/stemcells.2004-0331

Sun LY, Hsieh DK, Yu TC, et al., 2009. Effect of pulsed electromagnetic field on the proliferation and differentiation potential of human bone marrow mesenchymal stem cells. Bioelectromagnetics, 30(4):251-260.

https://doi.org/10.1002/bem.20472

Sun XJ, Gao X, Zhou LY, et al., 2013. PDGF-BB-induced MT1-MMP expression regulates proliferation and invasion of mesenchymal stem cells in 3-dimensional collagen via MEK/ERK1/2 and PI3K/AKT signaling. Cell Signal, 25(5):1279-1287. https://doi.org/10.1016/j.cellsig.2013.01.029

Sun ZC, Ge JL, Guo B, et al., 2016. Extremely low frequency electromagnetic fields facilitate vesicle endocytosis by increasing presynaptic calcium channel expression at a central synapse. Sci Rep, 6:21774. https://doi.org/10.1038/srep21774

Tamama K, Kawasaki H, Wells A, 2010. Epidermal growth factor (EGF) treatment on multipotential stromal cells (MSCs). Possible enhancement of therapeutic potential of MSC. J Biomed Biotechnol, 2010:795385. https://doi.org/10.1155/2010/795385

Tang LL, Jiang YA, Zhu MF, et al., 2020. Clinical study using mesenchymal stem cells for the treatment of patients with severe COVID-19. Front Med, 14(5):664-673. https://doi.org/10.1007/s11684-020-0810-9

Thibault RA, Baggett LS, Mikos AG, et al., 2010. Osteogenic differentiation of mesenchymal stem cells on pregenerated extracellular matrix scaffolds in the absence of osteogenic cell culture supplements. Tissue Eng Part A, 16(2):431-440. https://doi.org/10.1089/ten.TEA.2009.0583

Touchstone H, Bryd R, Loisate S, et al., 2019. Recovery of stem cell proliferation by low intensity vibration under simulated microgravity requires LINC complex. NPJ Microgravity, 5:11. https://doi.org/10.1038/s41526-019-0072-5

Tu C, Xiao YF, Ma YZ, et al., 2018. The legacy effects of electromagnetic fields on bone marrow mesenchymal stem cell self-renewal and multiple differentiation potential. Stem Cell Res Ther, 9:215. https://doi.org/10.1186/s13287-018-0955-5

Ude CC, Miskon A, Idrus RBH, et al., 2018. Application of stem cells in tissue engineering for defense medicine. 
Mil Med Res, 5:7.

https://doi.org/10.1186/s40779-018-0154-9

Volarevic V, Gazdic M, Markovic BS, et al., 2017. Mesenchymal stem cell-derived factors: immuno-modulatory effects and therapeutic potential. BioFactors, 43(5):633-644. https://doi.org/10.1002/biof.1374

Volarevic V, Markovic BS, Gazdic M, et al., 2018. Ethical and safety issues of stem cell-based therapy. Int $J$ Med Sci, 15(1):36-45. https://doi.org/10.7150/ijms.21666

Wang J, An YX, Li FJ, et al., 2014. The effects of pulsed electromagnetic field on the functions of osteoblasts on implant surfaces with different topographies. Acta Biomater, 10(2):975-985. https://doi.org/10.1016/j.actbio.2013.10.008

Wang LM, Wang LH, Cong XL, et al., 2013. Human umbilical cord mesenchymal stem cell therapy for patients with active rheumatoid arthritis: safety and efficacy. Stem Cells Dev, 22(24):3192-3202. https://doi.org/10.1089/scd.2013.0023

Wang SG, Hsu NC, Wang SM, et al., 2020. Successful treatment of plaque psoriasis with allogeneic gingival mesenchymal stem cells: a case study. Case Rep Dermatol Med, 2020:4617520. https://doi.org/10.1155/2020/4617520

Widowati W, Wijaya L, Bachtiar I, et al., 2014. Effect of oxygen tension on proliferation and characteristics of Wharton's jelly-derived mesenchymal stem cells. Biomarkers Genomic Med, 6(1):43-48. https://doi.org/10.1016/j.bgm.2014.02.001

Winer JP, Janmey PA, McCormick ME, et al., 2009. Bone marrow-derived human mesenchymal stem cells become quiescent on soft substrates but remain responsive to chemical or mechanical stimuli. Tissue Eng Part A, 15(1): 147-154. https://doi.org/10.1089/ten.tea.2007.0388

Wu LZ, Zhang GR, Guo CB, et al., 2020. Intracellular $\mathrm{Ca}^{2+}$ signaling mediates IGF-1-induced osteogenic differentiation in bone marrow mesenchymal stem cells. Biochem Biophys Res Commun, 527(1):200-206. https://doi.org/10.1016/j.bbrc.2020.04.048

Yan JH, Dong L, Zhang BH, et al., 2010. Effects of extremely low-frequency magnetic field on growth and differentiation of human mesenchymal stem cells. Electromagn Biol Med, 29(4):165-176. https://doi.org/10.3109/01676830.2010.505490

Yang YHK, Ogando CR, See CW, et al., 2018. Changes in phenotype and differentiation potential of human mesenchymal stem cells aging in vitro. Stem Cell Res Ther, 9:131. https://doi.org/10.1186/s13287-018-0876-3

Yong Y, Ming ZD, Feng L, et al., 2016. Electromagnetic fields promote osteogenesis of rat mesenchymal stem cells through the PKA and ERK1/2 pathways. $J$ Tissue Eng Regen Med, 10(10):E537-E545. https://doi.org/10.1002/term.1864

Zhang MS, Li XP, Bai LM, et al., 2013. Effects of low frequency electromagnetic field on proliferation of human epidermal stem cells: an in vitro study. Bioelectromagnetics, 34(1):74-80. https://doi.org/10.1002/bem.21747

Zhang XJ, Zhang JB, Qu XM, et al., 2007. Effects of different extremely low-frequency electromagnetic fields on osteoblasts. Electromagn Biol Med, 26(3):167-177. https://doi.org/10.1080/15368370701580756

Zhang Y, Ravikumar M, Ling L, et al., 2021. Age-related changes in the inflammatory status of human mesenchymal stem cells: implications for cell therapy. Stem Cell Reports, 16(4):694-707. https://doi.org/10.1016/j.stemcr.2021.01.021

Zhang YC, Yan JY, Xu HR, et al., 2018. Extremely low frequency electromagnetic fields promote mesenchymal stem cell migration by increasing intracellular $\mathrm{Ca}^{2+}$ and activating the FAK/Rho GTPases signaling pathways in vitro. Stem Cell Res Ther, 9:143. https://doi.org/10.1186/s13287-018-0883-4

Zhou J, He HC, Yang L, et al., 2012. Effects of pulsed electromagnetic fields on bone mass and Wnt/ $\beta$-catenin signaling pathway in ovariectomized rats. Arch Med Res, 43(4):274-282.

https://doi.org/10.1016/j.arcmed.2012.06.002 